\title{
The Effect and Mechanisms of Proliferative Inhibition of Crocin on Human Leukaemia Jurkat Cells
}

\author{
Y Sun ${ }^{1}$, Z Wang ${ }^{2}$, L Wang ${ }^{3}$, L-Z Wang ${ }^{1}$, C Zang ${ }^{4}$, L-R Sun ${ }^{1}$
}

\begin{abstract}
Targeted therapy is a potentially useful approach for the treatment of T-lineage acute lymphoblastic leukaemia. This study aimed to find a highly effective, low toxic anti-tumour drug and further investigate its mechanisms. Jurkat cells were used as the object and were stimulated by different concentrations of crocin. By cell count, growth curve, methyl thiazolyl tetrazolium (MTT) method for the detection of cell proliferation, annexin V/propidium iodide (PI) method for the apoptosis rates, and reverse transcription-polymerase chain reaction (RT-PCR) for Bcl-2 and Bax gene expression, the effect and mechanisms of proliferative inhibition of crocin on Jurkat cells were further explored. Crocin promoted Jurkat cell apoptosis and inhibited cell growth, in a dose-time-dependent manner. The mechanism might be related to the inhibition of Bcl-2 gene expression and the promotion of Bax gene expression. These results suggest that crocin can be used as a suitable clinical agent for the treatment of T-lineage acute lymphoblastic leukaemia.
\end{abstract}

Keywords: Anti-tumour, apoptosis, crocin, Jurkat cells

\section{Efecto y Mecanismos de la Inhibición Proliferativa de la Crocina en las Células Jurkat de la Leucemia Humana \\ Y Sun ${ }^{1}$, Z Wang ${ }^{2}$, L Wang ${ }^{3}$, L-Z Wang ${ }^{1}$, C Zang ${ }^{4}$, L-R Sun ${ }^{1}$}

\begin{abstract}
RESUMEN
La terapia dirigida es un método potencialmente útil para el tratamiento de la leucemia linfoblástica aguda de linaje T. Este estudio tuvo por objetivo encontrar un medicamento antitumoral de baja toxicidad y altamente eficaz, contra esta enfermedad, y seguir investigando sus mecanismos. Las células Jurkat fueron utilizadas como objeto y se les estimuló con diferentes concentraciones de crocina. El efecto y los mecanismos de inhibición proliferativa de crocina en células Jurkat fueron además explorados mediante recuento de células, curva de crecimiento, método metil tiazolil tetrazolio (MTT) para la detección de la proliferación celular, método anexina V/PI para las tasas de apoptosis, y la reacción en cadena reversa de la transcriptasa-polimerasa (RT-PCR) para la expresión del gen Bcl-2 y el gen Bax. La crocina promueve la apoptosis de las células Jurkat e inhibe el crecimiento celular, de manera dosistiempo dependiente. El mecanismo podría estar relacionado con la inhibición de la expresión del gen Bcl-2 y la promoción de la expresión del gen Bax. Estos resultados sugieren que la crocina puede utilizarse como agente clínico adecuado para el tratamiento de la leucemia linfoblástica aguda de linaje $T$.
\end{abstract}

Palabras claves: Antitumoral, crocina, apoptosis, células Jurkat

West Indian Med J 2015; 64 (5): 473

From: ${ }^{1}$ Department of Paediatric Haematology, ${ }^{2}$ Department of Pharmacy, the Affiliated Hospital of Qingdao University, Qingdao 266003, PR China, ${ }^{3}$ Department of Paediatrics, Yantai Yu Huang Ding Hospital Affiliated to Qingdao University, Yantai 264000, PR China and ${ }^{4}$ Department of Paediatrics, Wendeng Central Hospital of Weihai, Weihai 264400, PR China.

Correspondence: Professor L-R Sun, Department of Paediatric Haematology, The Affiliated Hospital of Qingdao University, Qingdao 266003, China. Email: sunlr@vip.sina.com

\section{INTRODUCTION}

Acute leukaemia is a haematopoietic malignancy and a serious threat to the health and safety of children, among whom acute lymphoblastic leukaemia (ALL) is more common. T-lineage acute lymphoblastic leukaemia (T-ALL) is a form of ALL, and its cure rates have been significantly improved due to the application of combination chemotherapy (1). However, because of being associated with many adverse factors, high 
relapse rate and five-year relapse-free survival (RFS) being far behind B-lineage acute lymphoblastic leukaemia [B-ALL] (2, $3)$, there are still many problems in clinical treatment, especially treatment of multidrug resistant (MDR) cases (4). In recent years, allogeneic haematopoietic stem cell transplantation and application of monoclonal antibodies provide a new method for the treatment of ALL, but its long-term efficacy is still uncertain. Therefore, in clinical treatment, choosing new anti-tumour drugs with a specific target, high efficiency and low toxicity to improve the continuous complete remission rate of T-ALL becomes the focus of the present study, and is of great significance for the prevention and treatment of T-ALL.

Over the years, tumours have been thought to be caused mainly by abnormal cell proliferation and differentiation. But modern medical research shows that some malignant cells, of which cell death process is severely disrupted due to apoptosis-related gene regulation disorder, have the characteristics of apoptosis blocked rather than malignant proliferation $(5,6)$. Bcl-2, the most striking in many genes involved in apoptosis, is related to the incidence and development of tumours and sensitivity to chemotherapeutic drugs (7). Drug resistance of tumour cells, the major cause of failure of chemotherapy, involves a number of factors, among which apoptosis is at the intersection of a variety of drug-resistant pathways (8). Thus, induction of apoptosis has been one of the hotspots of the treatment of cancer (9). However, heavy metal preparations used as inducers now have serious drug side effects which make them difficult for patients to adhere to.

There are rich resources of medicinal plants in China. A variety of low toxicity Chinese herbal medicine has been found to contain anti-tumour active ingredients and induce tumour cell apoptosis; their role and value in cancer therapy are getting more and more attention. Crocus sativus $\mathrm{L}$ has a variety of pharmacological effects, particularly anti-tumour effect. Crocin is the main active ingredient extracted from Crocus sativus L, and inhibition of protein kinase activity and oncogene expression is speculated as its mechanism of action. At present, the basic study on anti-tumour effect of crocin mainly includes the major role on solid tumours, such as colon cancer, ovarian cancer and other solid tumours. There is little research on leukaemia. So, in this study, Jurkat cells (human T-cell leukaemia cell line) were used as the object to examine the effect of different concentrations of crocin on the inhibition of Jurkat cells in vitro in order to further explore the possible mechanisms, which provide a theoretical basis for the clinical treatment of leukaemia.

\section{MATERIALS AND METHODS \\ Reagents}

Products of crocin and methyl thiazolyl tetrazolium (MTT) were purchased from Sigma. Annexin V488/Propidium Iodide (PI) Apoptosis Detection Kit was purchased from Invitrogen Life Technologies. Primer Bcl-2 and Bax were purchased from Shanghai SANGON Biotech. RNA Extraction Kit and RT-PCR
Kit were purchased from OMEGA. Jurkat cells were purchased from Shanghai Institute of Life Sciences, Chinese Academy of Sciences.

\section{Cell cultures}

Jurkat cells were cultured in RPMI-1640 medium with $10 \%$ fetal bovine serum (FBS) at $37{ }^{\circ} \mathrm{C}$ in a fully humidified atmosphere with $5 \% \mathrm{CO}_{2}$. Half of fresh medium was replaced every other day.

The test groups were divided into five subgroups according to different concentrations of crocin: group A ( 0.625 $\mathrm{mg} / \mathrm{mL})$, group $\mathrm{B}(1.25 \mathrm{mg} / \mathrm{mL})$, group $\mathrm{C}(2.5 \mathrm{mg} / \mathrm{mL})$, group $\mathrm{D}(5.0 \mathrm{mg} / \mathrm{mL})$ and group $\mathrm{E}(10 \mathrm{mg} / \mathrm{mL})$.

Cell morphology was observed by microscopy. Cells were counted when cultured for 12 hours, 24 hours, 36 hours and 48 hours, and a growth curve was drawn.

\section{Inhibition of cell proliferation}

Different groups of cells cultured for 24 hours and 48 hours were collected and incubated with $20 \mathrm{ul} \mathrm{MTT}$ for four hours, $400 \times \mathrm{g}$ centrifuged and supernatant separated; $150 \mathrm{ul}$ DMSO was added and oscillated for 10 minutes. The colorimetric changes were measured at $570 \mathrm{~nm}$.

The inhibition rate $=1-((\mathrm{OD}$ processing-OD dying $) /$ $(\mathrm{OD}$ control-OD dying) $\times 100 \%$, the optical density (OD) value of control group $\times 100 \%$

\section{Detection of apoptosis}

Different groups of cells cultured for 24 hours and 48 hours were collected, $400 \times \mathrm{g}$ centrifuged and supernatant separated, then resuspended with $100 \mu 11 \times$ annexin-binding buffer solution, 5 ul annexin $\mathrm{V}$ and $1 \mu \mathrm{l}$ PI were added and protected from light for 15 minutes, $400 \mu l 1 \times$ annexin-binding buffer solution was added again and the apoptotic rates were observed.

\section{Detection of Bcl-2 and Bax gene expression by RT-PCR} According to the instruction, RNA was extracted from different groups of Jurkat cells cultured for 24 hours and 48 hours, and cDNA was synthesized by reverse transcription (RT). The whole gene encoding Bcl-2 and Bax was obtained by polymerase chain reaction (PCR) amplification, using the forward primer of human bcl-2 5' - GGA GGA TTG TGG CCT TCT TTG -3' and the reverse primer of human Bcl-2 5' - GGT GCC GGT TCA GGT ACT CA -3'; the forward primer of human Bax 5' - CCA GCT GCC TTA GAC TGT GT-3' and the reverse primer of human Bax 5' - GGT TTA TTA CCC CCT CAA GAC CAC 3'. The internal reference is GAPDH, its forward primer 5' - AAC AGC CTC AAG ATC ATC AGC AA3 ' and the reverse primer 5' - GAC TGT GGT CAT GAG TCC TTC CA-3'. The PCR products were identified by $1.5 \%$ agarose gel electrophoresis and the optical density was scanned in ultraviolet light. 


\section{Statistical analysis}

The results are expressed as mean $\pm \mathrm{SD}$. The different groups were compared by analysis of variance (ANOVA) and least significant difference (LSD) method. Pearson correlation analysis method was used to analyse cell apoptosis and gene expression, and $p<0.05$ is considered statistically significant.

\section{RESULTS}

\section{Crocin on Jurkat cells proliferation}

\section{Cell morphology}

The control group: Jurkat cells showed round contours, transparent and uniform cytoplasm, good refraction and the appearance of a bunch of grapes in suspension.

The test groups: Jurkat cells showed shrunken body, weakened refraction and increasing intracellular particles. With the crocin concentration of $5 \mathrm{mg} / \mathrm{mL}$ and $10 \mathrm{mg} / \mathrm{mL}$, cells were a single suspended growth (Fig. 1).

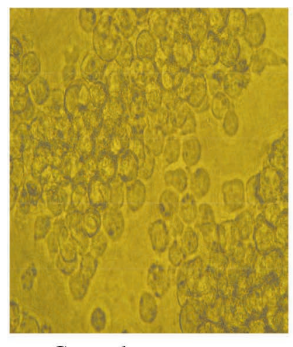

Control

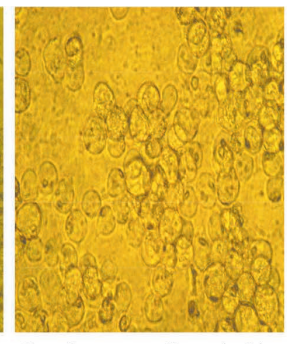

Crocin group $(5 \mathrm{mg} / \mathrm{mL})$

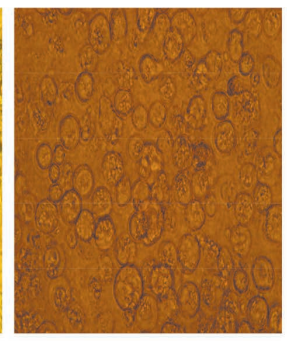

Crocin group $(10 \mathrm{mg} / \mathrm{mL})$
Fig. 1: The morphology of Jurkat cells cultured for 48 hours. The cells of the control group showed round contours, transparent and uniform cytoplasm, good refraction and appearance of a bunch of grapes in suspension. With the crocin concentration of $5 \mathrm{mg} / \mathrm{mL}$ and $10 \mathrm{mg} / \mathrm{mL}$, cells showed shrunken body, weakened refraction, increasing intracellular particles and a single suspended growth.

\section{Cell count}

Cultured for 24 hours: With the increase of crocin concentration from $1.25 \mathrm{mg} / \mathrm{mL}$ to $10 \mathrm{mg} / \mathrm{ml}$, the number of cells was significantly lower than that of the control group and group A $(0.625 \mathrm{mg} / \mathrm{mL})$.

Cultured for 48 hours: The number of cells in every test group was dramatically reduced.

The number of cells stimulated by the crocin concentration of $5 \mathrm{mg} / \mathrm{mL}$ and $10 \mathrm{mg} / \mathrm{mL}$ was the lowest, but there was no statistical significance (Table 1, Fig. 2).

Table 1: Cell count at different times and different concentrations of crocin $\left(\bar{x} \pm \mathrm{SD} ; \times 10^{5}\right)$

\begin{tabular}{lcc}
\hline Crocin $(\mathbf{m g} / \mathbf{m L})$ & Cell count & $\left(\times \mathbf{1 0}^{\mathbf{5}}\right)$ \\
& $\mathbf{2 4 h}$ & $\mathbf{4 8 h}$ \\
\hline Control 0 & $7.5 \pm 0.62$ & $14.0 \pm 1.72$ \\
Group A 0.625 & $7.2 \pm 0.41$ & $9.5 \pm 1.15^{*}$ \\
Group B 1.25 & $6.7 \pm 0.45^{*}$ & $8.2 \pm 0.94^{*}$ \\
Group C 2.5 & $5.5 \pm 0.34^{*}$ & $7.0 \pm 0.63^{*}$ \\
Group D 5.0 & $4.1 \pm 0.23^{*}$ & $2.5 \pm 0.27^{*}$ \\
Group E 10 & $3.8 \pm 0.35^{*}$ & $2.2 \pm 0.22^{*}$ \\
\hline
\end{tabular}

${ }^{*} p<0.05$, compared with control group

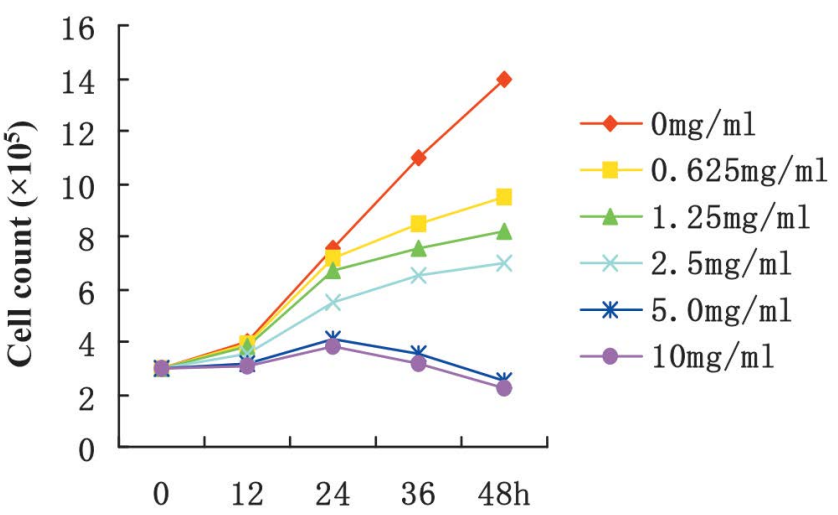

Fig. 2: Cell count at different times and different concentrations of crocin.

\section{Inhibition rates of cells proliferation}

Cultured for 24 hours: With the increase of crocin concentration from $1.25 \mathrm{mg} / \mathrm{mL}$ to $10 \mathrm{mg} / \mathrm{mL}$, the inhibition rates of cell proliferation were higher than those of the control group and group A (0.625 mgmL).

Cultured for 48 hours: The inhibition rates of cell proliferation in test groups were significantly increased.

The inhibition rates of crocin on cell proliferation were the highest in group D $(5.0 \mathrm{mg} / \mathrm{mL})$ and group $\mathrm{E}(10 \mathrm{mg} / \mathrm{mL})$, but there was no statistical significance. With the same concentration of crocin at 48 hours, the inhibition rates were significantly higher than those at 24 hours (Table 2).

Table 2: The inhibition rates of cells at different times and different concentrations of $\operatorname{crocin}(\% ; \bar{x} \pm \mathrm{SD})$

\begin{tabular}{lcc}
\hline Crocin $(\mathbf{m g} / \mathbf{m L})$ & Inhibition rates & $\mathbf{( \% )}$ \\
& $\mathbf{2 4 h}$ & $\mathbf{4 8 h}$ \\
\hline Control 0 & $1.826 \pm 0.025$ & $2.002 \pm 0.011^{\#}$ \\
Group A 0.625 & $3.566 \pm 0.025$ & $16.082 \pm 2.236^{* \#}$ \\
Group B 1.25 & $34.174 \pm 1.042^{*}$ & $53.080 \pm 2.503^{* \#}$ \\
Group C 2.5 & $43.582 \pm 1.745^{*}$ & $67.346 \pm 1.678^{* \#}$ \\
Group D 5.0 & $70.116 \pm 1.603^{*}$ & $84.932 \pm 1.337^{* \#}$ \\
Group E 10 & $71.086 \pm 1.756^{*}$ & $86.041 \pm 2.067^{* \#}$ \\
\hline
\end{tabular}

${ }^{*} p<0.05$, compared with control group; ${ }^{*} p<0.05$, compared between 24 hours and 48 hours

\section{Crocin on Jurkat cells apoptosis}

Cultured for 24 hours, the apoptotic rates of Jurkat cells in group B $(1.25 \mathrm{mg} / \mathrm{mL})$, group C $(2.5 \mathrm{mg} / \mathrm{mL})$, group D $(5.0$ $\mathrm{mg} / \mathrm{mL})$ and group E $(10 \mathrm{mg} / \mathrm{mL})$ were significantly higher than those of the control group and group A $(0.625 \mathrm{mg} / \mathrm{mL})$. Cultured for 48 hours, with increased crocin concentration from $0.625 \mathrm{mg} / \mathrm{mL}$ to $10 \mathrm{mg} / \mathrm{mL}$, the apoptotic rates in test groups were significantly increased. The rates of apoptosis were the highest in group D $(5.0 \mathrm{mg} / \mathrm{mL})$ and group E $(10$ $\mathrm{mg} / \mathrm{mL}$ ), but of no statistical significance. With the same concentration of crocin, the rates at 48 hours were significantly higher than those at 24 hours (Table 3, Fig. 3). 
Table 3: The apoptotic rates of cells at different times and different concentrations of crocin $(\% ; \bar{x} \pm \mathrm{SD})$

\begin{tabular}{lcc}
\hline Crocin (mg/mL) & \multicolumn{2}{c}{ Apoptotic rates } \\
& $\mathbf{2 4 h}$ & $\mathbf{4 8 h}$ \\
\hline Control 0 & $0.347 \pm 0.208$ & $0.580 \pm 0.300$ \\
Group A 0.625 & $2.107 \pm 0.417$ & $9.150 \pm 1.010^{* \#}$ \\
Group B 1.25 & $6.830 \pm 1.080^{*}$ & $12.540 \pm 1.490^{* \#}$ \\
Group C 2.5 & $9.167 \pm 1.478^{*}$ & $19.060 \pm 1.601^{* \#}$ \\
Group D 5.0 & $21.950 \pm 1.725^{*}$ & $38.980 \pm 1.712^{* \#}$ \\
Group E 10 & $22.850 \pm 1.541^{*}$ & $40.220 \pm 1.243^{* \#}$ \\
\hline
\end{tabular}

${ }^{*} p<0.05$, compared with control group; ${ }^{*} p<0.05$, compared between 24 hours and 48 hours

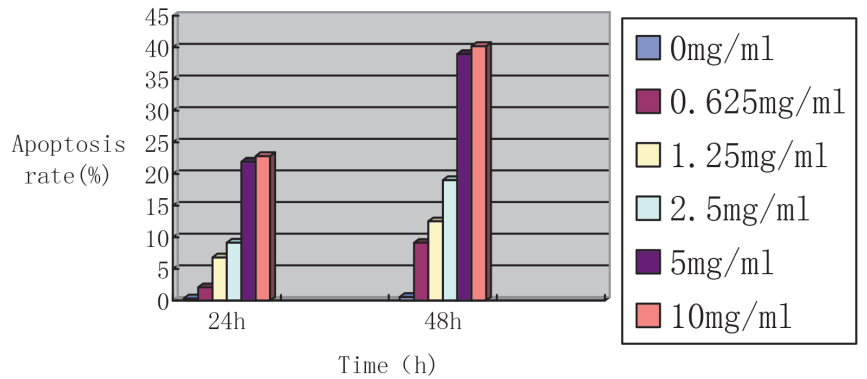

Fig. 3: The apoptotic rates of cells at different times and different concentrations of crocin.

\section{Expression of Bcl-2 gene and Bax gene}

Bcl-2 gene expression: Cultured for 24 hours, with the increase of crocin concentration from $1.25 \mathrm{mg} / \mathrm{mL}$ to $10 \mathrm{mg} / \mathrm{mL}$, the ratios of greyscale scan were significantly lower than those of the control group and group A $(0.625 \mathrm{mg} / \mathrm{mL})$. Cultured for 48 hours, the ratios of greyscale scan in test groups were dramatically reduced, among which groups $\mathrm{D}(5.0 \mathrm{mg} / \mathrm{mL})$ and $\mathrm{E}(10$ $\mathrm{mg} / \mathrm{mL}$ ) were the lowest, but there was no statistical significance. The ratios of greyscale scan at 48 hours were lower than those at 24 hours with the same concentration of crocin (Table 4, Fig. 4).

Table 4: Expression of Bcl-2 gene by reverse transcription-polymerase chain reaction $(\bar{x} \pm \mathrm{SD})$

\begin{tabular}{lll}
\hline Crocin $(\mathbf{m g} / \mathbf{m L})$ & \multicolumn{2}{c}{ Bcl-2 } \\
& $\mathbf{2 4 h}$ & $\mathbf{4 8 h}$ \\
\hline Control 0 & $0.802 \pm 0.017$ & $0.794 \pm 0.026$ \\
Group A 0.625 & $0.782 \pm 0.015$ & $0.685 \pm 0.020^{* \#}$ \\
Group B 1.25 & $0.702 \pm 0.017^{*}$ & $0.646 \pm 0.018^{* \#}$ \\
Group C 2.5 & $0.636 \pm 0.020^{*}$ & $0.547 \pm 0.023^{* \#}$ \\
Group D 5.0 & $0.536 \pm 0.022^{*}$ & $0.420 \pm 0.016^{* \#}$ \\
Group E 10 & $0.515 \pm 0.021^{*}$ & $0.398 \pm 0.017^{* \#}$ \\
\hline
\end{tabular}

${ }^{*} p<0.05$, compared with control group; ${ }^{*} p<0.05$, compared between 24 hours and 48 hours

Bax gene expression: As shown in Table 5 and Fig. 5, the ratios of greyscale scan cultured for 24 hours in groups B $(1.25 \mathrm{mg} / \mathrm{mL}), \mathrm{C}(2.5 \mathrm{mg} / \mathrm{mL}), \mathrm{D}(5.0 \mathrm{mg} / \mathrm{mL})$ and $\mathrm{E}(10$
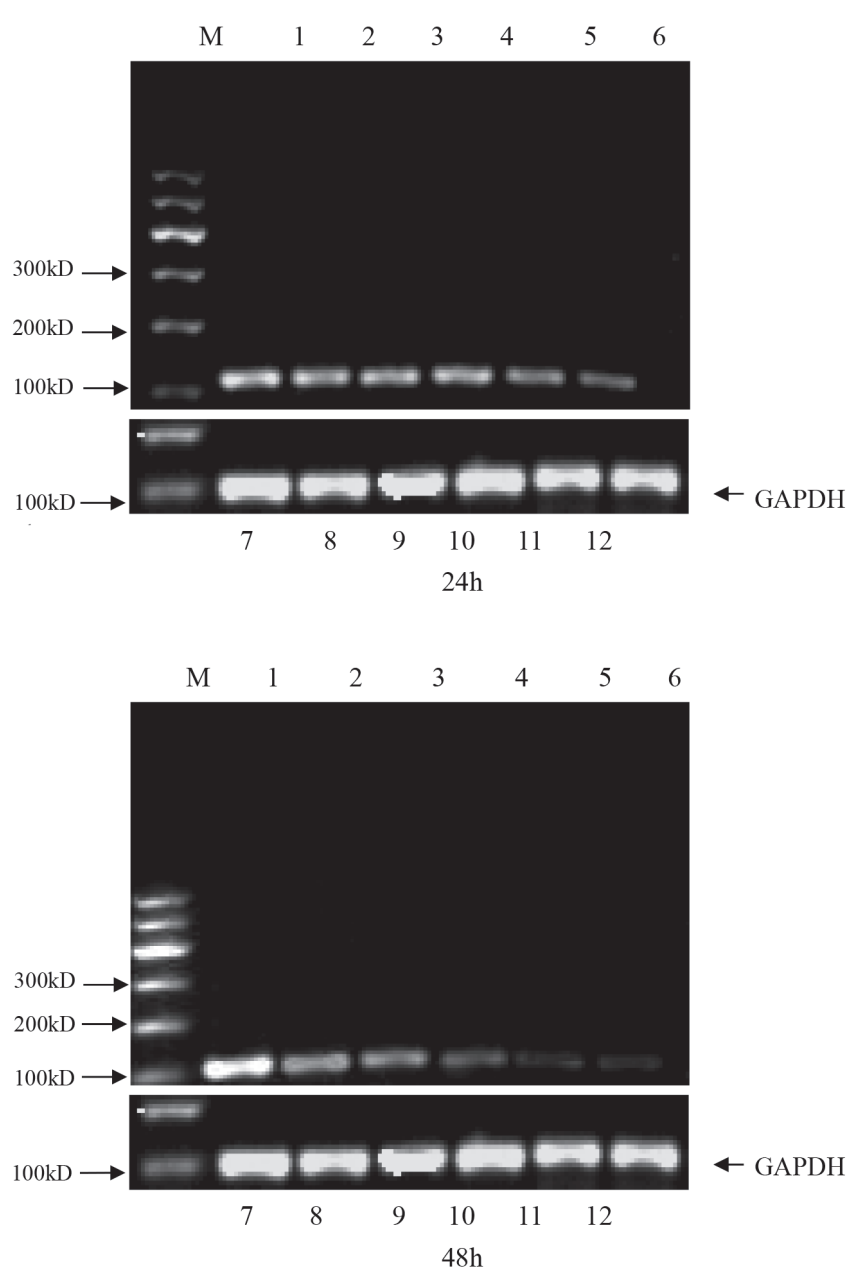

Fig. 4: Expression of Bcl-2 gene at different concentrations of crocin. M: Marker; Lanes 7-12: GAPDH; Lane 1: $0 \mathrm{mg} / \mathrm{mL}$; Lane 2: $0.625 \mathrm{mg} / \mathrm{mL}$; Lane 3: $1.25 \mathrm{mg} / \mathrm{mL}$; Lane 4:2.5mg/mL; Lane 5:5 mg/mL; Lane $6: 10 \mathrm{mg} / \mathrm{mL}$

$\mathrm{mg} / \mathrm{mL}$ ) were higher than those of the control group and group A $(0.625 \mathrm{mg} / \mathrm{mL})$. Cultured for 48 hours, with the increase of crocin concentration from $0.625 \mathrm{mg} / \mathrm{mL}$ to $10 \mathrm{mg} / \mathrm{mL}$, the ratios of greyscale scan in the test groups were significantly increased. Those of 48 hours were dramatically higher than 24 hours (Table 5, Fig. 5).

Table 5: Expression of Bax gene by reverse transcription-polymerase chain reaction $(\bar{x} \pm \mathrm{SD})$

\begin{tabular}{lll}
\hline Crocin $(\mathbf{m g} / \mathbf{m L})$ & \multicolumn{2}{c}{ Bax } \\
& $\mathbf{2 4 h}$ & $\mathbf{4 8 h}$ \\
\hline Control 0 & $0.634 \pm 0.019$ & $0.649 \pm 0.023$ \\
Group A 0.625 & $0.664 \pm 0.016$ & $0.792 \pm 0.022^{* *}$ \\
Group B 1.25 & $0.767 \pm 0.020^{*}$ & $0.827 \pm 0.016^{* \#}$ \\
Group C 2.5 & $0.837 \pm 0.020^{*}$ & $0.926 \pm 0.014^{* *}$ \\
Group D 5.0 & $0.920 \pm 0.017^{*}$ & $1.047 \pm 0.017^{* \#}$ \\
Group E 10 & $0.931 \pm 0.015^{*}$ & $1.071 \pm 0.019^{* \#}$ \\
\hline
\end{tabular}

${ }^{*} p<0.05$, compared with control group; ${ }^{*} p<0.05$, compared between 24 hours and 48 hours 

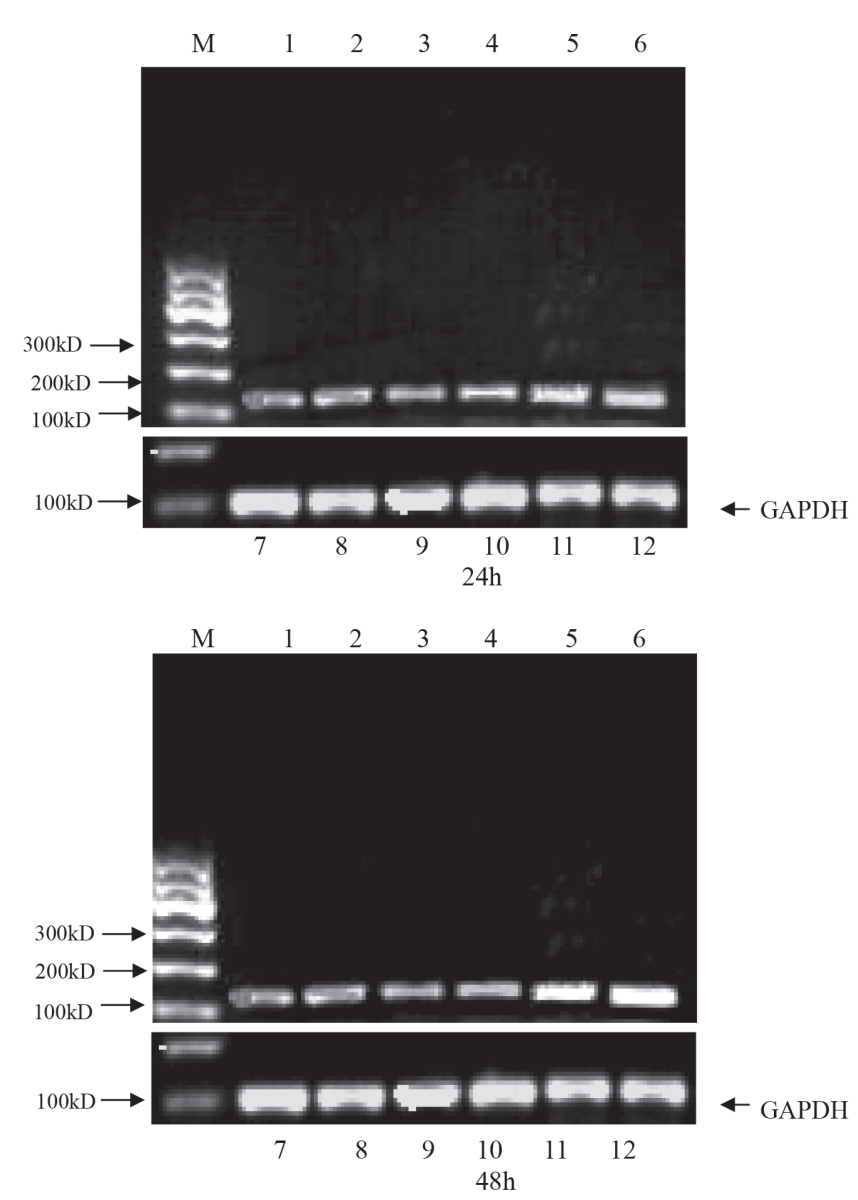

Fig. 5: Expression of Bax gene at different concentrations of crocin. M: Marker; Lanes 7-12: GAPDH; Lane 1: $0 \mathrm{mg} / \mathrm{mL}$; Lane 2: 0.625 $\mathrm{mg} / \mathrm{mL}$; Lane 3: $1.25 \mathrm{mg} / \mathrm{mL}$; Lane 4: $2.5 \mathrm{mg} / \mathrm{mL}$; Lane $5: 5 \mathrm{mg} / \mathrm{mL}$; Lane $6: 10 \mathrm{mg} / \mathrm{mL}$.

\section{Apoptosis and gene expression}

Bcl-2 and apoptosis: Pearson correlation coefficient was $0.964, p=0.00$, showing a strong negative linear correlation. Bax and apoptosis: Pearson correlation coefficient was 0.957 , $p=0.00$ and showed a strong positive linear correlation.

Bcl-2 and Bax: Pearson correlation coefficient was $-0.983, p=$ 0.00 and showed a strong negative linear correlation (Fig. 6).

\section{DISCUSSION}

Application of combination chemotherapy can result in the long-term remission rate of acute leukaemia in children of 70 to $80 \%$ (10), but multidrug chemotherapy lacks specificity, and the side effects have been many and after a long period of continuous intensive chemotherapy, there may be relapse resistant to treatment.

Crocus sativus L, also known as saffron, is a precious traditional Chinese medicine known as "plant gold" $(11,12)$. Modern medical research has found that Crocus sativus $\mathrm{L}$ has a broad-spectrum anti-tumour activity. It has a strong inhibitory effect on leukaemia cells (HL-60 and K562), papillary tumour cells, colon cancer, and rhabdomyosarcoma (12,
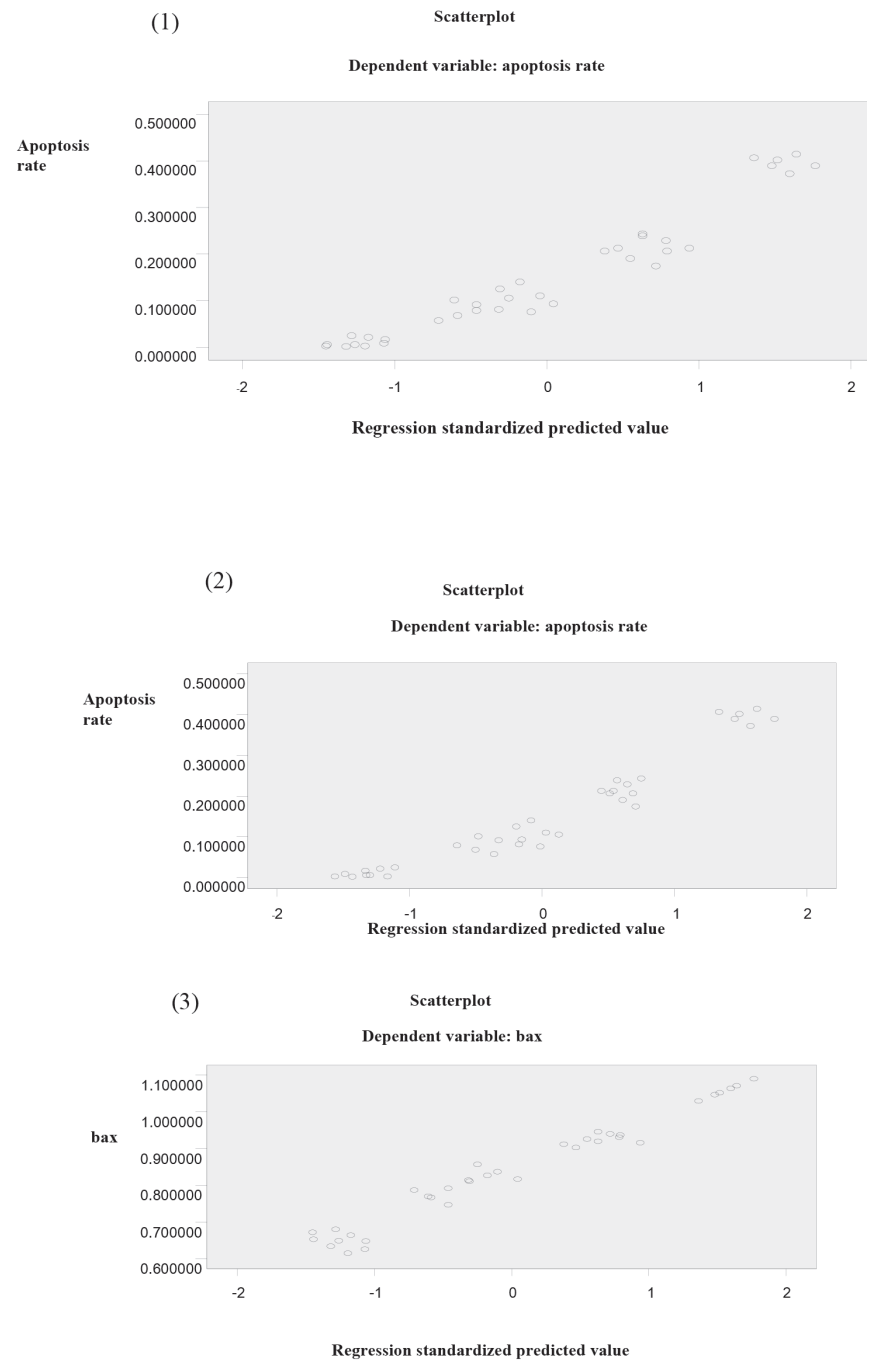

Fig. 6: Apoptosis and gene expression. (1) bcl-2 and apoptosis; (2) bax and apoptosis; (3) bcl-2 and bax.

13), but few side effects on normal cells $(14,15)$. When used in combination with other anticancer drugs, it is expected to reduce the toxic side effects (16). Therefore, Crocus sativus $\mathrm{L}$ becomes the research focus of the new anticancer drugs.

At present, about 40 to 50 kinds of Crocus sativus L have been identified, among which the components with anti-cancer effects are saffron extract, crocetin and crocin $(17,18)$. Crocin is the most important beneficial pigment of Crocus sativus $\mathrm{L}$, formed due to glycosylation, and extremely rare water-soluble carotenoids (19). With its water solubility and high inhibitory characteristics, crocin is considered to be one of the most promising anticancer drugs in the ingredients of Crocus sativus L. Preliminary studies of our group found that crocin had a significant anti-tumour effect on HL-60 cells in vitro. It could induce cell apoptosis and inhibit cell growth, and its mechanism was to increase the Bax gene expression and reduce Bcl2 gene expression, so that the cells were blocked at G0/G1 phase (20). The question is whether crocin also has the same anti-tumour effectiveness on Jurkat cells? 
In this study, we observed that crocin had a strong inhibition on the Jurkat cells. With the increase in crocin concentration and time, the number of cells gradually reduced and the inhibition rates gradually increased, among which the concentrations of $5 \mathrm{mg} / \mathrm{mL}$ and $10 \mathrm{mg} / \mathrm{mL}$ for 48 hours were the most obvious. It showed that the inhibition of crocin on the proliferation of Jurkat cells was in a dose-time-dependent manner, which is consistent with the inhibition of crocin on other tumour cell proliferation (21-24).

Apoptosis is also known as programmed cell death and can occur any time in the cell cycle phase and different sources of cells have different start points $(25,26)$. Annexin V, which is a calcium-dependent phospholipid binding protein and specifically combines with the phosphatidylserine exposure to the outer membrane, is one of the sensitive indicators to detect early apoptosis. Propidium iodide is a nucleic acid dye, and can highlight the nuclei of late apoptosis of cells and dead cells with red dye. Therefore, in this study, we used two-parameter annexin V/PI flow analysis to distinguish apoptotic cells from dead cells in order to detect the apoptotic rates of crocin induced on Jurkat cells.

The results showed that the apoptosis rates of the experimental groups gradually increased with the increase of crocin concentration and time, among which the concentration of 5 $\mathrm{mg} / \mathrm{mL}$ and $10 \mathrm{mg} / \mathrm{mL}$ for 48 hours were the highest $(38.98 \pm$ $1.71 \%$ and $40.22 \pm 1.24 \%$, respectively). However, MTT assay measured that the inhibition rates of the same concentration and point were $84.93 \pm 1.34 \%$ and $86.04 \pm 2.07 \%$. There was a larger difference and the causes may be: (i) with the combination of annexin-V and PI, the apoptotic cells in early stages, late stages and necrotic cells could be distinguished. So, application of this method measured the early apoptotic rates of Jurkat cells, but did not include late apoptosis and necrotic cells. (ii) The anti-tumour mechanism of crocin has not been elucidated and there may be other mechanisms besides apoptosis. So the apoptotic rates detected by the annexin V488/PI flow cytometry were lower than the inhibition rates measured by MTT.

Initiation and conduction of apoptosis involve multiple genes and products. It is the exact process regulated by genes and mainly consists of two approaches: one is that the death receptors on the cell membrane activate the cysteine protease Caspase, and the other is that the apoptotic factors released by the mitochondrial pathway activate the expression of Caspase. The activated Caspase can stimulate the degradation of important proteins within cells to cause apoptosis. The most striking in many genes involved in apoptosis is Bcl-2, and its expression levels can change significantly the impedance in tumour cell lines to apoptosis induced by chemotherapeutic drugs $(27,28)$. In this study, detection of $\mathrm{Bcl}-2$ and Bax gene expression by RT-PCR showed that within the concentration of crocin $0.625 \sim 10 \mathrm{mg} / \mathrm{mL}$ cultured for 24 hours, Bcl-2 expression began to decline and Bax expression increased. With the increase of crocin concentration and time, Bcl-2 expression gradually decreased and Bax expression gradually in- creased; Bcl-2 gene expression and apoptosis showed a strong negative linear correlation, and Bax gene expression and apoptosis showed a strong positive linear relation. This suggested that down-regulation of Bcl-2 expression and up-regulation of Bax expression might be involved in the process of apoptosis induced by crocin on Jurkat cells.

All the results showed that crocin could promote Jurkat cell apoptosis and inhibit cell growth. The mechanism might be related to the inhibition of Bcl-2 gene expression and the promotion of the Bax gene expression. However, from different levels and multiple targets, the exact mechanism of crocin to influence gene expression, subsequently resulting in tumour apoptosis, has to be further studied.

\section{REFERENCES}

1. Ye CL, Lv YQ, Luo YR, Liu JJ, Lv JH, Ren XD et al. Inhibition of the proliferation of Jurkat cells by biclofenac. J Jinan Univ (Natural Science and Medicine Edition) 2002; 23: 17-21.

2. Pui CH. Acute lymphoblastic leukemia in children. Curr Opin Onco1 2000; 12: 3-12.

3. Constan-Smith E, Sancho J, Hancook ML, Boyett JM, Behm FG, Raimondi SC. Clinical importance of minimal residual disease in childhood acute lymphoblastic leukemia. Blood 2000; 96: 2691-6.

4. Lai A, Kwan E, Haber M, Norris MD, Marshall GM. Detection of minimal residual disease in peripheral blood prior to clinical relapse of childhood acute lymphoblastic leukemia using PCR. Mol Cell Probes 2001; 15: 99-103.

5. Yao SJ, Liu BY, Zhong ZH. Experimental study of anti-tumor effect of ELE on liver cancer. J Qiqihar Med Coll 2006; 27: 257-60.

6. Favrot M, Coil JL, Louis N. Cell death and cancer: replacement of apoptotic genes and inactivation of death suppressor genes in therapy. Gene Ther 1998; 5: 728-33.

7. Ma XJ, Ren HB, Ye L. Research process the expression of Bcl-2 and Bax in acute leukemia. Clinical Medical Journal of China 2005; 12: 955-7.

8. De Luca V, Mundo E, Trakalo J, Wong GWH, Kennedy JL. Investigation of polymophism in the MDR1 gene and antidepressant-induced mania. Pharmacogenomics 2003; 3: 297-9.

9. Li CT, Li WH, Wu ZH, Sun YW. HL-60 apoptosis induced by samarium complex of N- (4-carboxyphenyl) retinami and its molecular mechanism. Pract J Cancer 2003; 18: 11-3.

10. Huang SL, Zhou DH. Treatment for childhood leukemia by hematopoietic stem cell transplantation. J Clin Pediatr 2007; 8: 625-8.

11. Abdullaev FI, Espinosa-Aguirre JJ. Biomedical properties of saffron and its potential use in cancer therapy and chemoprevention trials. Cancer Detect Prev 2004; 28: 426-32.

12. Hosseinzadeh H, Modaghegh MH, Saffari Z. Crocus sativus L. (saffron) extract and its active constituents (crocin and safranal) on ischemia-reperfusion in rat skeletal muscle. Evid Based Complement Alternat Med 2009; 6: $343-50$.

13. Hosseinzadeh H, Younesi HM. Antinociceptive and anti-inflammatory effects of Crocus sativus L. stigma and petal extracts in mice. BMC Pharmacol 2002; 2: 7. doi: 10.1186/1471-2210-2-7.

14. Abdullaev Jafarova F, Caballero-Ortega H, Riveron-Negrete L, PeredaMiranda R, Rivera-Luna R, Manuel Hernández J et al. [In vitro evaluation of the chemopreventive potential of saffron]. Rev Invest Clin 2002; 54: 430-6. In Spanish

15. Abdullaev FI, Riveron-Negrete L, Caballero-Ortega H, Manuel Herandez J, Perez Lopez I, Pereda Miranda R et al. Use of in vitro assays to assess the potential antigenotoxic and cytotoxic effects of saffron (Crocus sativus L). Toxicol In Vitro 2003; 17: 731-6.

16. Premkumar K, Abraham SK, Santhiya ST. Inhibition of genotoxicity by saffron (Crocus sativus L) in mice. Drug Chem Toxicol 2004; 24: 421-8.

17. Asdaq SM, Inamdar MN. Potential of Crocus sativus (saffron) and its constituent, crocin, as hypolipidemic and antioxidant in rats. Appl Biochem Biotechnol 2010; 162: 358-72. 
18. Ahmad AS, Ansari MA, Ahmad M, Saleem S, Yousuf S, Hoda MN et al. Neuroprotection by crocetin in a hemi-parkinsonian rat model. Pharmacol Biochem Behav 2005; 81: 805-13.

19. Abdullaev FI, Espinosa-Aguirre JJ. Biomedical properties of saffron and its potential use in cancer therapy and chemoprevention trials. Cancer Detect Prev 2004; 28: 426-32.

20. Xu HJ, Zhong R, Zhao YX, Li XR, Lu Y, Song AQ et al. [Proliferative inhibition and apoptotic induction effects of crocin on human leukemia HL-60 cells and their mechanisms]. J Exper Hematol 2010; 18: 887-92. In Chinese

21. Magesh V, Singh JP. Antitumour activity of crocetin in accordance to tumour incidence, antioxidant status, drug metabolizing enzymes and histopathological studies. Mol Cell Biochem 2006; 287: 127-32.

22. Garcia DC, Riese HH, Escribano J. Effects of long-term treatment of colon adenocarcinoma with crocin, a carotenoid from saffron (Crocus sativus L.): an experimental study in the rat. Nutr Cancer 1999; 35: $120-6$.
23. Bakshi HA, Sam S, Feroz A. Crocin from Kashmiri saffron (Crocus sativus) induces in vitro and in vivo xenograft growth inhibition of Dalton's lymphoma (DLA) in mice. Asian Pac J Cancer Prev 2009; 10: 887-90.

24. Aung HH, Wang CZ, Ni M. Crocin from Crocus sativus possesses significant anti-proliferation effects on human colorectal cancer cells. Exp Oncol 2007; 29: 175-80.

25. Thompson CB. Apoptosis in the pathogenesis and treatment of disease. Science 1995; 267: 1456-62.

26. Hickma JA. Apoptosis in cancer therapy: crossing the threshold. Cell 1994; 78: 539-42.

27. Wong N, Diao CT, Wong M. The overexpression of Bcl-2 antagonizes the proapoptotic function of the kappa-opioid receptor. Ann N Y Acad Sci 2003; 1010: 358-60.

28. Guo LJ, Wu ZY, Zhang S, Zheng JL, Zheng HL. Effect of bcl-2 antisense oligonueleotides on multidrug resistance of cultured uveal melanoma cells. Chinese J Ophthalmol 2003; 39: 73-6. 